PRZEGLĄD RUSYCYSTYCZNY 2021, nr 1 (173)

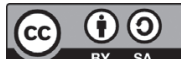

DOI 10.31261/pr.7967

\author{
OLGA PAULINA SIEMOŃSKA \\ Uniwersytet Wrocławski \\ (D) ORCID: http://orcid.org/0000-0003-0128-2997
}

\title{
MOTYWY TANATYCZNE I AUDIALNE W OPOWIEŚCI DINY RUBINY ВЫСОКАЯ ВОДА ВЕНЕЦИАНЦЕВ
}

\begin{abstract}
THANATIC AND PHONIC MOTIFS
IN THE WORK OF DINA RUBINA ВЫСОКАЯ ВОДА ВЕНЕЦИАНЦLЕВ (VYSOKAYA VODA VENETSIANTSEV)

The work of Dina Rubina Высокая вода венецианцев (Vysokaya voda venetsiantsev 1999) stands out among other texts of Venetian themes thanks to more detailed descriptions of the soundscape of the city. The article aims to analyze the Venetian phonosphere in the work of Rubina, using the potential of sensory literary geography, as well as soundstudies. In the course of the analysis of individual descriptions of sounds, it turns out that the reason for distinguishing the sound elements in the image of the city was, first of all, the musical education of the author. It is also explained that the image of Venice, including its phonosphere, is shown in the text through the prism of the literary tradition, according to which Venice is portrayed as the "city of death,"'the dying city," 'the city of the dying".

Keywords: Dina Rubina, Venice, soundscape, Venetian text
\end{abstract}

Na literackiej mapie Europy Wenecja zajmuje miejsce szczególne. Świadczy o tym nie tylko liczba poświęconych jej utworów literackich, ale również siła, z jaką wyobraźnia wypiera w obrazach miasta poznanie empiryczne, sprawiając, że przybiera ono formę przestrzeni baśniowej, wręcz nadprzyrodzonej. Niemałe znaczenie ma również fakt, że fascynacja tym miastem wspólna jest dla przedstawicieli wielu różnych literatur narodowych. Bogata w treści o tematyce weneckiej jest także literatura rosyjska. Badacze zajmujący się rosyjską „wenecjaną” wskazali wiele zagadnień oraz cech dystynktywnych, wokół których budowany jest literacki obraz Wenecji. Są to m.in. lustrzaność, ambiwalentność, schematyzm, metafizyka․ Rozwój nowych tendencji

1 Zob. Л. Лосев, Реальность зазеркалья: Венеция Иосифа Бродского, „Иностранная литература” 1996, nr 5, http://magazines.russ.ru/inostran/1996/5/ losev.html (28.03.2019); Н.Е. Меднис, Венеция в русской литературе. Ново- 
$\mathrm{w}$ humanistyce, związanych, po pierwsze, z tzw. zwrotem topograficznym $^{2}$, a po drugie, $\mathrm{z}$ przejściem $\mathrm{w}$ badaniach antropologicznych od kwestii dotyczących kultur pierwotnych, ich religii i etniczności ku zainteresowaniu kulturą własną $a^{3}$ umożliwia poszerzenie perspektywy badawczej i uwzględnienie takich, dotychczas niedostatecznie zbadanych kwestii jak percepcja zmysłowa miasta oraz jej literackie reprezentacje. Narzędzi do tego typu refleksji dostarczają m.in. literacka antropologia miejsc, geopoetyka, antropologia zmysłów, sound studies czy łącząca założenia metodologiczne wymienionych nurtów sensoryczna geografia literacka, przedstawiona przez Elżbietę Rybicką w monografii Geopoetyka. Przestrzeń i miejsce we wspótczesnych praktykach literackich ${ }^{4}$.

Celem przedstawionego tu szkicu jest analiza pejzażu dźwiękowego Wenecji w opowieści Diny Rubiny Высокая вода венецианцев (1999), wykorzystująca potencjał sensorycznej geografii literackiej, a konkretnie perspektywy dźwiękowej (sound studies) w literaturoznawczych badaniach nad tekstem weneckim. Podjęta zostanie próba określenia roli dźwięku w literackim obrazie Wenecji, a także wpływu pewnych kodów kulturowych na percepcję kluczowych elementów środowiska fonicznego miasta. Uwagi i komentarze powiązane zostaną z dominującymi w utworze motywami tanatycznymi.

Problem krajobrazu dźwiękowego w utworze Высокая вода венецианцев to kwestia złożona, wymagająca uwzględnienia trzech co najmniej kwestii.

сибирск 1999, https://libking.ru/books/sci-/sci-philology/457906-nina-mednisvenetsiya-v-russkoy-literature.html (12.11.2019); Т. Цивьян, „Золотая голубятня у воды...” Венеция Ахматовой на фоне других русских Венеций, w: tejże, Семиотические путешествия, ИД Ивана Лимбаха, Санкт-Петербург 2001.

2 O zwrocie topograficznym, inicjującym zainteresowanie przestrzenią, jako nadrzędną kategorią w refleksji humanistycznej, szczegółowo pisze Elżbieta Rybicka: E. Rybicka, Od poetyki przestrzeni do polityki miejsca. Zwrot topograficzny $w$ badaniach literackich, w: tejże, Geopoetyka. Przestrzeń i miejsce we wspótczesnych teoriach i praktykach literackich, Universitas, Kraków 2014.

3 W drugiej połowie XX wieku obszar refleksji antropologicznej zostaje poszerzony o zagadnienia związane z kulturą współczesnych społeczeństw postindustrialnych, co związane jest z postmodernistycznym przekonaniem o niemożności obiektywnego spojrzenia na „innego”, który do tej pory stanowił główny przedmiot zainteresowań antropologów. Zob. K. Górny, Antropologia, współczesności czy kultury? „Zeszyty Etnologii Wrocławskiej” 2016, nr 1.

4 „,...] celem literackiej geografii sensorycznej będzie badanie sensualnych krajobrazów (dźwiękowych, zapachowych, wizualnych), których świadectwem są reprezentacje literackie oraz poszukiwanie kodów kulturowych kształtujących percepcję miejsc i przestrzeni”. Zob. E. Rybicka, Od poetyki przestrzeni..., s. 248. 
Po pierwsze, Wenecja przez wielu pisarzy uważana jest za przestrzeń „wzrokocentryczną”, dlatego w tworzeniu jej obrazu literackiego dominującą rolę odgrywają bodźce wzrokowe. Utwór Diny Rubiny Высокая вода венецианцев jest jednym z nielicznych w rosyjskim tekście weneckim, w których doświadczenie audialne potraktowane zostało na równi z doświadczeniem wizualnym.

Po drugie, na wykreowany w opowieści obraz przestrzeni sensorycznej Wenecji wpływ miały nie tylko uwarunkowania kulturowe i geograficzne miasta, ale również indywidualne kompetencje autorki tekstu (zwłaszcza wykształcenie muzyczne).

Po trzecie, pod wpływem tradycji literackiej, zgodnie z którą Wenecja postrzegana jest w kulturze jako „miasto śmierci”, „miasto umierające” czy też „miasto umierających”, pejzaż dźwiękowy opisany w utworze zyskał dodatkowe sensy.

Dariusz Czaja w artykule Szmery, szepty krzyki. Muzyka weneck $a^{5}$ zaznacza, że na przeszkodzie pełnemu, multisensorycznemu doświadczaniu miasta staje dominująca w postrzeganiu przestrzeni weneckiej rola pierwiastka wizualnego, co zauważyć można w wielu tekstach literackich poruszających temat Wenecji ${ }^{12}$. Również Gleb Smirnow w książce Метафизика Венеции (2017) pisze, że to miasto jest przestrzenią dominacji obrazu. Podkreśla jednocześnie, że wybitni wenecjanie to $\mathrm{w}$ przeważającej większości mistrzowie pędzla. Smirnow przywołuje doświadczenie Aleksandra Błoka, któremu panujący w Wenecji „terror oka” odebrał wiarę w moc potencjału twórczego słowa:

Блок был заворожен плотной, вещественно наполненной призрачностью Венеции, когда хочется спросить: что значит все это? Она выступала как художественный вызов, но Блок не видел в поэзии, по крайней мере своей, средств, чтобы ухватить ее и в письме к матери писал: „здесь хочется быть художником, а не писателем”.

W inny sposób tę samą myśl wyraził kilka dziesięcioleci później Jarosław Iwaszkiewicz w Podróżach do Włoch (1997):

Wszystko tu jest obrazem - i nie potrzeba tego uzupełniać ani pędzlem, ani słowem. Canaletto to tylko fotografował. Ja nie mam potrzebnego aparatu?

5 D. Czaja, Szmery, szepty, krzyki. Muzyka wenecka, „Prace Kulturoznawcze” 2012, nr 13 .

${ }^{6}$ Г. Смирнов, Метафизика, ОГИ, Москва 2017, s. 116-117.

7 J. Iwaszkiewicz, Podróże do Włoch, PIW, Warszawa 1997, s. 25-26. 
Również Josif Brodski na pierwszych stronach eseju Znak wodny (Watermark, 1992) zaznacza, że woli postawić się w roli malarza pejzażysty, który rejestruje to, co widzi niż myśliciela, dla którego pobyt w Wenecji jest pretekstem do snucia rozważań natury filozoficznej:

dalszy ciąg tych wywodów będzie miał związek raczej z okiem niż z ustalonymi poglądami [...]. Oko wyprzedza pióro - i zdecydowany jestem nie dopuścić do tego, aby moje pióro określało swoją pozycję niezgodnie z prawdą. [...] Wpatrując się w twarz tego miasta przez siedemnaście zim, zyskałem już zapewne zdolność do machnięcia czegoś całkiem przekonującego w stylu Poussina: do namalowania podobizny Wenecji, jeśli nie w czterech porach roku, to w czterech porach dnia ${ }^{8}$.

„Władza oka” w postrzeganiu przestrzeni weneckiej mimo że wydaje się bezsporna, nie oznacza, że miasto to nie wysyła innych bodźców zmysłowych. Dźwięk, choć zdominowany przez obraz i pozbawiony absolutnej władzy nad oczarowanym niezwykłymi widokami obserwatorem, wydaje się interesującą i złożoną oraz, jak zauważa Czaja, „żywą i niezwykle istotną znaczeniowo częścią szeroko rozumianej weneckiej semiosfery" 9 . Odbiorcy wrażliwi audialnie wychwytują i rejestrują osobliwości weneckiej przestrzeni dźwiękowej, która wraz ze sferą wrażeń wzrokowych, zapachowych i dotykowych składa się na całość doświadczenia sensorycznego, przyczyniając się do powstania określonej wizji miasta. Badacz, analizując kilka wybranych utworów, dochodzi do wniosku, że dźwięki w nich obecne tworzą specyficzną dla miasta audiosferę:

geniusz dźwiękowej Wenecji polega na tym, że jest ona fenomenem całości. Idzie o to, że wszystkie wymienione elementy występują tu na ograniczonej i stosunkowo wąskiej przestrzeni. Więcej, mogą nawet wystąpić w jednym czasie! W dodatku wszystko dzieje się w przestrzeni zamkniętej. Wenecja działa jak rezonator, potężna studnia czuła na każdy najlżejszy odgłos pojawiający się w jej przestrzeni. [...] Dlatego tak trudno dokładnie i do końca je nazwać, dlatego piszący pozostają najczęściej na poziomie prostej rejestracji słuchowych wrażeń ${ }^{10}$.

W opowieści Diny Rubiny Высокая вода венецианцев sfera foniczna Wenecji oddziałuje na podmiot równie silnie jak sfera wizu-

8 J. Brodski, Znak wodny, przel. S. Barańczak, Zeszyty Literackie, Warszawa 2016, s. 18.

9 D. Czaja, Szmery, szepty..., s. 59.

${ }^{10}$ Tamże, s. 68. 
alna. Autorka w swoich „sonotopografiach” - opisach krajobrazów dźwiękowych, nie przedstawia dźwięków „zwyczajnych”, brzmienia codzienności, lecz przywołuje te charakterystyczne dla Wenecji zjawiska akustyczne, które odnieść można do zaproponowanej przez Raymonda Murraya Schafera ${ }^{11}$ kategorii soudmarks, czyli dźwiękowych wizytówek, symboli, sygnatur danego miejsca. Tekst Rubiny z założenia nie jest pełnym i obiektywnym obrazem weneckiej audiosfery. Opisany w nim krajobraz audialny, podobnie jak pozostałe krajobrazy zmysłowe, został podporządkowany pewnym kodom kulturowym. Sposób, w jaki rejestrowane przez podmiot dźwięki korespondują z tradycyjnymi wyobrażeniami o Wenecji, wpisuje się w stale obecny w światowej wenecjanie motyw „miasta śmierci”.

Uważa się, że osadzony głęboko w wyobraźni europejskiej związek śmierci z Perłą Adriatyku ma źródło w utopijnej idei miasta na wodzie, tworu wzniesionego na przekór naturze i od jej kaprysów zależnego. Upadek Republiki Weneckiej w 1797 roku, obracające się w ruinę pałace oraz ciągłe zagrożenie ze strony niszczycielskiego żywiołu morza utrwaliły w kulturze wizerunek miasta umierającego, miasta grobu, mauzoleum, cmentarza. Mniej więcej od połowy XIX wieku motywy tanatyczne i wanitatywne rozwijają się w tekście weneckim na dwóch płaszczyznach. Pierwsza z nich oparta jest na wyłaniającym się z wielu tekstów przekonaniu o kruchości Wenecji, jej efemeryczności i nieuchronności czekającej ją zagłady. Druga, bezpośrednio wynikająca z pierwszej, ma związek ze szczególnym typem bohatera literackiego, który Kazimierz Mrówka, znawca tematyki weneckiej, określa łacińską frazą homo moribundus - człowiek umierający. Mrówka o specyficznej więzi łączącej człowieka umierającego z Wenecją, więzi, której istotą jest ciągła walka ze śmiercią, chwiejne, niepewne zawieszenie pomiędzy istnieniem i unicestwieniem. Ten stan tragicznego trwania na styku karnawałowej radości życia i chaosu śmierci interpretuje on w odniesieniu do heraklitejskiej jedności przeciwieństw: „zmagające się ze sobą przeciwieństwa nadają sobie nawzajem blasku - śmierć i życie nabierają w Wenecji pełni, wyrazistości, dosadności, podobnych do intensywności weneckiego światła

${ }^{11}$ Muzykolog Raymond Murray Schafer zapoczątkował w latach 70. badania nad szeroko pojętym środowiskiem dźwiękowym. Jest twórcą takich pojęć jak soundscape (krajobraz / pejzaż dźwiękowy), earwitness (autor wiarygodnego opisu pejzażu dźwiękowego) czy soundmark. Zob. R. Murray Schafer, The Soundscape. Our Sonic Enviroment and the Tuning of the World, Destiny Books, Rochester, Vermont 1994. 
uwodzącego umysł artysty" ${ }^{\prime 2}$. Odpowiada to tradycji literackiej, zgodnie z którą Wenecja przedstawiana jest jako miejsce, do którego na pewnym etapie podróży, często końcowym, trafiają osoby zagubione, w taki czy inny sposób nieszczęśliwe: tułacze, uciekinierzy, ludzie chorzy, starzy lub samotni:

Этот город близок и понятен уставшим, утратившим цель и смысл жизни, тем, кому остались только воспоминания о прошедшем, потому что и сама Венеция - тоже воспоминанье ${ }^{13}$.

Miasto, niczym swego rodzaju „lustro psychologiczne”"14, odzwierciedla przeżycia tych, którzy utracili wiarę w przyszłość i szukają ukojenia. Można w tym kontekście przywołać postać rewolucjonisty Insarowa z powieści $W$ przededniu (Накануне, 1860) Iwana Turgirniewa, Milly Theales, bohaterke Skrzydet gotębicy (The Wings of the Dove, 1902) Henry'ego Jamesa, Gustava Aschenbacha ze Śmierci $w$ Wenecji (Der Tod in Venedig, 1913) Tomasza Manna, a z literatury najnowszej - trójkę outsiderów z powieści Смерть современных героев (1992) Eduarda Limonowa czy poetę Stasa Perfeckiego z utworu Jurija Andruchowycza Perwersja (Перверзія, 2004). W literaturze rosyjskiej tego rodzaju sposób przedstawiania Wenecji zaczyna kształtować się już w połowie XIX wieku i dominuje w liryce ${ }^{15}$. Lew Łosiew zauważa, że „старость, воспоминания о утратах, близость конца” to motywy charakterystyczne dla późnych utworów weneckich Piotra Wiaziemskiego ${ }^{16}$. Z kolei autorzy artykułu Венеция в русской поэзии $X I X-X X$ веков za pierwszy utwór, w którym w pełni ujawnia się korelacja między obrazem miasta a stanem emocjonalnym i losem bohatera lirycznego, uważają wiersz Apollona Grigoriewa $\mathrm{Ve}$ nezia la bella $(1857)^{17}$. Źródeł tego modelu obrazowania miasta należy szukać w sposobie, w jaki Wenecja oddziaływała i wciąż oddziałuje na przybysza, budząc w nim uczucie melancholii, wzruszając widokiem więdnącego piękna i zgasłej potęgi, prowokując myśli o śmierci.

Otaczająca Wenecję mistyczna aura wabi nad lagunę Insarowa z powieści Turgieniewa, postaci wykreowane przez Manna, Jamesa,

${ }^{12}$ K. Mrówka, Wenecja, Wydawnictwo Formicula, Kraków 2009, s. 125.

${ }_{13}$ М. Гладышева, А. Криницын, Венеция в русской поэзии XIX - XX веков, „Litera” 2018, nr 1, https://www.e-notabene.ru/fil/article_25264.html (27.03.2019).

${ }^{14}$ Н. Е. Меднис, Венеция в русской...

${ }_{15}$ М. Гладышева, А. Криницын, Венеция в русской поэзии...

16 Л. Лосев, Реальность зазеркалья: Венеция Иосифа Бродского...

${ }_{17}$ М. Гладышева, А. Криницын, Венеция в русской поэзии... 
a także parę zakochanych z opowiadania Biała noc miłości Gustawa Herlinga-Grudzińskiego oraz bohaterów utworów Lecha Majewskiego, Jurija Andruchowycza czy Eduarda Limonowa. Powieść Metafizyka Majewskiego oraz będący przedmiotem niniejszej analizy utwór Высокая вода венецианцев Diny Rubiny wykorzystują podobny schemat fabularny - oba teksty przedstawiają wędrówkę po Wenecji jako swego rodzaju rytuał odejścia, inicjację w śmierć. Zasadniczą oś tematyczną tych dzieł stanowi duchowy związek umierającego człowieka z umierającym miastem. Bohaterki obu tekstów chorują na raka i pod wpływem odbierającej nadzieję diagnozy postanawiają udać się do Wenecji. Przebywanie i poruszanie się po tej jakby zawieszonej między światami, widmowej, fantasmagorycznej krainie przynosi ukojenie, pociesza, przygotowuje do tego, co nieuchronne. Katarzyna Szalewska nazywa ten sposób przemieszczania się bohatera literackiego po mieście „pielgrzymowaniem”. Przeciwstawia je dryfowaniu, które z założenia jest bezcelową włóczęgą, błądzeniem. Pielgrzymowanie zaś zakłada cel - jest wędrowaniem ku śmierci ${ }^{18}$. $\mathrm{W}$ utworze Rubiny ważną rolę w tym osobliwym misterium śmierci pełni sfera dźwięków, będąca swego rodzaju medium, za pomocą którego miasto porozumiewa się z bohaterką.

Opowieści Высокая вода венецианцев charakteryzuje się nietypową dla tekstu weneckiego zmysłową różnorodnością. Świat przedstawiony utworu, w równym stopniu co kształty i kolory, wypełniają dźwięki. Nierzadko pojawiają się w nim zapachy. Sfera akustyki przestrzeni weneckiej jest szczególnie bogata. Bohaterka utworu, postać sensualnie i estetycznie wrażliwa, zwraca uwagę na pojawiające się w jej otoczeniu dźwięki: śpiew i okrzyki gondolierów, bicie dzwonów, muzykę organową, odgłosy codzienności. Synergia wrażeń wizualnych i dźwiękowych wywołuje silną reakcję emocjonalną podmiotu percepcji, spotęgowaną dodatkowo świadomością zbliżającej się śmierci. Sytuacja psychologiczna, w której znajduje się kobieta, zmienia sposób odbierania bodźców sensualnych. Można przypuszczać, że doświadczanie Wenecji, w tym jej audiosfery, w innych okolicznościach, nie naznaczonych widmem choroby, miałoby zgoła inny charakter, bardziej powierzchowny, konwencjonalny, pozbawiony głębszego znaczenia, chciałoby się rzec rozrywkowy, „turystyczny”. Dotyczy to zwłaszcza pieśni wykonywanych przez gondolierów. Istnienie profesji gondoliera $\mathrm{w}$ czasach współczesnych nie wiąże się

${ }^{18}$ K. Szalewska, Urbanalia - miasto i jego teksty, Słowo/obraz terytoria, Gdańsk 2017, s. 73-74. 
w żaden sposób z realnymi potrzebami mieszkańców miasta. Z powodzeniem zastępują oni gondole motorówkami i tramwajami wodnymi. Śpiew gondoliera, służący obecnie jedynie celom komercyjnym, jest więc niekiedy postrzegany jako zjawisko trywialne, uwłaczające wyrafinowanym gustom.

Над водой разносилась надрывная «Бесамемучо»... - О-и! - крикнул гондольер перед тем, как завернуть за угол дома напротив, оттолкнулся от стены ногой в крассовке и, выровняя гондолу, запел еще надрывнее - работал на туристов ${ }^{19}$.

Wzmianka o sportowym obuwiu gondoliera, niewspółgrającym z potocznym, „romantycznym” wyobrażeniem o nim, ujawnia zdystansowany, a nawet nieco pobłażliwy stosunek bohaterki utworu do tego faktu. Podobną funkcję mają słowa „работал на туристов”, które jednoznacznie sugerują, że „przejmujący śpiew” wioślarza, jest według kobiety jedynie sposobem przyciągnięcia uwagi potencjalnych klientów. Analizując kolejne zdania utworu, można jednak zauważyć, że o ile ten komentarz cechuje pewna ironia, to następująca po nim gwałtowna, emocjonalna reakcja postaci stoi w całkowitej sprzeczności z postawą prześmiewcy czy choćby trzeźwego obserwatora:

Она отпрянула от окна, сказав себе: - Нет, этого не может быть! Дикая мысль, что ее послали сюда затем чтобы... ступить, шагнуть с подоконника посреди этих оперных декораций - уйти на дно лагуны, раствориться в гобеленовой пасторали лодочек и гондол, исчезнуть ... словом, отколоть номерок ${ }^{20}$.

Gwałtowna reakcja emocjonalna bohaterki stoi w opozycji do charakteru postrzeganych przez nią elementów otoczenia. W obrazowaniu dominuje pierwiastek prześmiewczy, o czym świadczy użycie wyrażeń „оперные декорации” і „гобеленовая пастораль лодочек и гондол", sugerujących, z jednej strony, pewną teatralność, czy nawet pretensjonalność, z drugiej, naiwną idylliczność obserwowanej sceny. Jednocześnie słyszane dźwięki nieoczekiwanie dla samej bohaterki silnie oddziałują na jej uczucia, co ma niewątpliwie źródło $\mathrm{w}$ trawiącym ją lęku tanatycznym. W obliczu śmierci podziały na to, co wyrafinowane i eleganckie oraz to, co pospolite i nieoryginalne,

${ }^{19}$ Д. Рубина, Высокая вода венецианцев, Litres, Москва 2017 (цифровое издание).

${ }^{20}$ Tamże, s. 15 . 
tracą sens. Pieśń gondoliera nie jest więc odbierana przez pryzmat „dobrego smaku”, lecz poprzez zawarty w niej ładunek emocjonalny. Popularna piosenka siłą oddziaływania wyzwala tłumioną rozpacz, a następnie przynosząc ulgę, oczyszczając, sugeruje remedium - samobójstwo, szybkie i łatwe pozbycie się psychicznej udręki, jaką jest świadomość długiego i upokarzającego umierania.

Podobną, być może nawet silniejszą reakcję emocjonalną bohaterki wywołuje wykonywane na organach kościoła San Giorgio Maggiore Preludium Bacha:

И вдруг вся мощь басов тридцатидвухфутовых труб органа потрясла церковь от купола до каменных плит пола: ошалелый восторг, слезный спазм, дрожь перед чем-то непроизносимо великим, как воды, прорвавшие дамбу, - обрушились на нее, и в какой-то миг этого разрывавшего ее счастья она поняла, что мечтает сейчас же, немедленно уйти на дно лагуны, сидя на этой вот скамье, в этой церкви, вместе с ее великолепным куполом и колокольней, статуями, картинами Тинторетто... ${ }^{21}$

Towarzyszące słuchaniu organów uczucie zostaje zestawione z obrazem rzeki przerywającej tamę. Woda, przez wielu pisarzy przedstawiana jako istota Wenecji i jednocześnie jej największy wróg, jest kluczowym symbolem tanatycznym światowej wenecjany. Jej ciemną otchłań Paweł Muratow nazwał wodami Lety - wodami zapomnienia $^{22}$. Peter Ackroyd dostrzega w niej źródło owej „fatalnej siły przyciągania”, która sprawia, że do Wenecji przybywają ci, którzy szukają ucieczki, azylu i pocieszenia w obliczu śmierci ${ }^{23}$. Kazimierz Mrówka pisze, że woda jest zwierciadłem, w którym Wenecja przegląda się, „kontemplując kostuchę" ${ }^{24}$. W utworze Rubiny woda występuje pod postacią aqua alta, cyklicznej powodzi, zwiastującej miastu los mitycznej Atlantydy. Bohaterce utworu wizja potopu jawi się, z jednej strony, jako zjawisko fascynujące, a nawet urzekające, z drugiej zaś, jako budzący grozę apokaliptyczny chaos. „Ошалелый восторг, слезный спазм, дрожь перед чем-то непроизносимо великим" 25 - takimi słowami opisuje ona uczucie wywołane dźwiękami utworu Bacha, które, przywołując obraz rozszalałego żywiołu, po raz kolejny wzywają do „pogrążenia się w wody laguny”. Myśl

${ }^{21}$ Tamże, s. 23.

${ }^{22}$ P. Muratow, Obrazy Włoch. Wenecja, przeł. P. Hertz, Zeszyty Literackie, Warszawa 2009, s. 11.

${ }^{23}$ P. Ackroyd, Wenecja. Biografia, przeł. T. Bieroń, Zysk i S-ka, Poznań 2015, s. 344.

${ }^{24}$ K. Mrówka, Wenecja..., s. 113.

25 Д. Рубина, Высокая..., s. 23. 
o połączenia własnego losu z losem umierającego miasta podnosi na duchu, kusi uniknięciem tego, co w śmierci najbardziej przerażające - samotności.

Należy zauważyć, że zarówno w kontekście pieśni gondoliera, jak i Preludium pojawia się wzmianka sugerująca związek omawianych zdarzeń akustycznych z mistycznym, nadprzyrodzonym oddziaływaniem Wenecji na człowieka umierającego, którego miasto zdaje się wzywać do siebie, przyciągać, mamić. „Мысль, что ее послали сюда" niepokoi bohaterkę obserwującą scenę z gondolierem. Ponownie refleksja ta nawiedza ją kościele San Giorgio Maggiore:

а может быть, ее приволокли сюда именно из сострадания - показать райские картины, подать некий успокаивающий, уливающийся знак: мол, не бойся, не бойся, дорогая ${ }^{26}$.

Poczucie związku duchowego łączącego chorą kobietę ze skazanym na zagładę miastem najsilniej ujawnia się jednak w porze uaktywnienia się dzwonnic weneckich kościołów.

Wzmianki o dźwięku dzwonów pojawiają się w opowieści kilka razy. Na zasadzie kontrastu ze „statecznymi”, „potężnymi” dzwonami Amsterdamu, dźwięk ten zostaje określony jako iluzoryczny, nierealny, który w zestawieniu z wodą - drżącym zwierciadłem ukazującym jakby inną rzeczywistość - wpisuje się w obraz „miasta nie z tego świata”, miasta fantasmagorii:

Странно отличается здешний колокольный звон от такового в Амстердаме. Там - устойчивость, могучая основательность бюргеров. Здесь - мираж, отражение в воде канала, вопрошающий гул рока... ${ }^{27}$

Wieczorne bicie weneckich dzwonów zostaje nazwane pieriezwonem. W tradycji cerkiewnej terminem tym określa się kolejne uderzenia w różnej wielkości dzwony, które rozbrzmiewając, wygrywają szczególny koncert. Wenecki pieriezwon jest jednakże polirytmiczny, sprawia wrażenie kakofonii:

Опять заговорили жалобно, перебивая друг друга, колокола соседних церквей, им отвечал с Сан-Марко ровный гуд, на фоне которого всплескивали верхние колокола ${ }^{28}$.

${ }^{26}$ Tamże, s. 25.

${ }^{27}$ Tamże, s. 30.

${ }^{28}$ Tamże, s. 38. 
Сначала ударили на колокольне Сан-Марко, и минуты две на одной гудящей ноте гул раскачивал сам себя, потом с колокольни одной из соседних церквей - Сан Джулиано, или Санта-Мария Формоса стали выпадать равномерные густые басы, иногда роняя невпопад какие-то случайные бимы и бомы ${ }^{29}$.

Na nieuporządkowany charakter melodii dźwięków wskazują epitety „случайный” oraz „невпопад”. Przymiotnik sugeruje przypadkowość i nieprzewidywalność zdarzenia akustycznego, przysłówek zaś jego nietrafność, omyłkowość lub też niestosowność. Podobną funkcję pełnią sformułowania „колокола заговорили, перебивая друг друга” і „колокола всплескивали”, które pogłębiają metaforyczność opisu. Imiesłów „перебивая” w zestawieniu z czasownikiem „заговорили”, nawiązując do rozmowy prowadzonej w sposób emocjonalny, gwałtowny i chaotyczny, odnosi się do grupy dźwięków możliwych do zaobserwowania jedynie w obszarze działalności człowieka. Słowo „всплескивать” ma związek z odgłosami wydawanymi przez wodę lub inną substancję ciekłą w momencie zaburzenia statyczności jej powierzchni, wskazuje więc na zakłócenie pewnej równowagi czy też utratę płynności.

W tym kontekście warto zaznaczyć, że na kakofoniczny charakter weneckiego pieriezwonu zwrócił uwagę także Jarosław Iwaszkiewicz. W Opowiadaniu z kotem (1964) zawarł opis wieczornego „koncertu” dzwonów, zaznaczając, że chaotyczność dźwięków dochodzących z dzwonnic Wenecji wyróżnia to miasto na tle innych:

W tej chwili uderzyły dzwony. Jak to w Wenecji, nie jednocześnie i nieporządnie. Miedziany głos u prawosławnego świętego Jerzego, potem u świętego Marka, jak sygnaturka, a potem wszystkie. Ale nie biły razem, akordami, lecz odzywały się do siebie jak kukułki w lesie, to tu, to ówdzie. W dali uderzył potężny ton raz jeden, a bliżej dzwony dzwonily w rozsypanego ${ }^{30}$.

Wielowarstwowość opisu sfery fonicznej, zawierającego chociażby rozróżnienie dźwięku dzwonów poszczególnych kościołów, wyraźna jest w utworach obojga pisarzy. Ma to niewątpliwie związek z faktem, że zarówno Rubina, jak i Iwaszkiewicz otrzymali wyksztalcenie muzyczne ${ }^{31}$, co uwrażliwiło tych twórców na nieuchwytne dla prze-

${ }^{29}$ Tamże, s. 27.

${ }^{30} \mathrm{~J}$. Iwaszkiewicz, Opowiadanie z kotem, w: tegoż, O psach, kotach $i$ diabłach, Czytelnik, Warszawa 1968, s. 37.

${ }^{31}$ Jarosław Iwaszkiewicz pobierał pierwsze lekcje gry na fortepianie już we wczesnym dzieciństwie. W latach 1912-1918 studiował w konserwatorium w Kijowie. 
ciętnego człowieka subtelności obecne w przestrzeni dźwiękowej. W utworach Josifa Brodskiego, który poświęcił Wenecji znaczną część swojej twórczości, opisy niedzielnego pieriezwonu, mimo ich obrazowości, nie są już tak szczegółowe „muzykologicznie”. Podmiot liryczny w wierszu Лагуна (1973) nie słyszy pojedynczych dźwięków, lecz odbiera je jako brzęczącą, wibrującą całość - i to właśnie ta całość wpływa na jego stan emocjonalny. Dina Rubina natomiast zwraca uwagę nie tylko na psychoakustyczne oddziaływanie dźwięków dzwonu na podmiot percepcji, ale także na ich barwę, wysokość czy współbrzmienie. W opisach tych łączy terminologię muzyczną z obrazowaniem poetyckim, aby przekonująco przedstawić stan uczuciowy bohaterki:

звонарь Сан-Марко, торопясь, перебрал подряд все колокола вверх и в обратном порядке - по малым терциям, да по малым септимам, - терзая сердце жалобными протяжными вопросами ${ }^{32}$.

W Opowiadaniu z kotem Iwaszkiewicz akcentuje chaotyczność dźwięku dzwonów poprzez porównanie ich do odgłosów wydawanych przez kukułki, w utworze Rubiny bicie dzwonów zostaje nazwane rozmową, w związku z czym można mówić nawet o personifikacji idiofonu („колокола заговорили”), a nawet całej dzwonnicy:

И долго разговаривали колокольни окрестных церквей, перебивая друг друга, вскрикивая, захлебываясь лепетом маленьких колоколов, увязая, как в киселе, в тревожном густом гуле ${ }^{33}$.

Fragment ten stanowi rozbudowaną metaforę, której celem jest przedstawienie zależności znaczeniowej między weneckim pieriezwonem i gwałtowną, emocjonalną, żywiołową dyskusją. Wskazuje na to użycie imiesłowów „перебивая”, „вскрикивая” і „захлебываясь”, a także rzeczownika „лепет”, oznaczającego mowę niewyraźną, niezrozumiałą, bełkotliwą lub gaworzenie niemowlęcia.

Obdarzanie dzwonów cechami ludzkimi jest dość częstym zabiegiem literackim, wywodzącym się z wierzeń ludowych. Dzwonom

Zob. G. Piotrowski, Fortepian ze Stawska. Muzyka $w$ prozie fabularnej Jarosława Iwaszkiewicza, Wydawnictwo Adam Marszałek, Toruń 2010, s. 22-24. Dina Rubina ukończyła Specjalistyczną Szkołę Muzyczną przy taszkienckim konserwatorium, w której uczyła się gry na fortepianie. Zob. http://www.dinarubina.com/biography.html (28.03.2019).

$3^{2}$ Д. Рубина, Высокая..., s. 27.

33 Tamże, s. 27. 
przypisywano właściwości apotropaiczne, uważano je za istoty uduchowione, władające mocą magiczną, zdolne przepędzić zło. Źródeł takiej antropomorfizacji można doszukiwać się również $\mathrm{w}$ tradycji chrześcijańskiej, zgodnie z którą nowo odlany dzwon chrzczono i nadawano mu imię, jego dźwięk zaś nazywano głosem lub mową ${ }^{34}$. Inskrypcje umieszczane na dzwonach kościelnych sugerowały, że autorem przekazu jest sam dzwon: „Chwalę prawdziwego Boga, zwołuję lud, gromadzę duchownych, opłakuję zmarłych, oddalam zarazę, zdobię świat, głos mój jest postrachem wszelkich demonów"35.

W utworze Rubiny takie sformułowania jak „жалобный, протяжный вопрос”, „вопрошающий гул рока”, „вопросительный протяжный стон” określają intonację „głosu dzwonów”. W tych przypadkach zastosowanie zabiegu antropomorfizacji wskazuje na rodzaj relacji między narratorem i bohaterem. Mimo że narracja prowadzona jest $w$ trzeciej osobie, podmiotem percepcji jest bez wątpienia postać doktor Łurie, a opisywane dźwięki można uznać za projekcję jej uczuć. Postrzeganie przez bohaterkę dźwięku dzwonu jako wypowiedzi człowieka, który pyta, prowokuje i wzywa, wynika z jej stanu emocjonalnego i potrzeby refleksji egzystencjalnej. Przyjazd do Wenecji ma bowiem ułatwić znalezienie odpowiedzi na pytania jak zachować się w obliczu ciężkiej choroby i prawdopodobnej śmierci, jak poradzić sobie ze strachem i bólem, jak przygotować bliskich na swoją śmierć. Atmosfera „miasta śmierci” sprzyja takim przemyśleniom, co w omawianym utworze wyraźnie widać także w momentach uaktywnienia się przestrzeni dźwiękowej. Słuchanie śpiewu gondolierów, wykonywanego na organach Preludium Bacha oraz wieczornego „koncertu” dzwonów wpływa na stan psychiczny bohaterki, potęgując jej reakcję emocjonalną: z jednej strony rodzi uczucie zachwytu i wzruszenia pięknem, z drugiej wywołuje przerażenie i rozpacz.

W opowieści dzwony Wenecji mają zdolność przywoływania widm przeszłości, ożywiania wspomnień, wyrażają rozpacz, strach i tęsknotę, co potwierdza barwa ich dźwięku, opisana za pomocą epitetów „густой”, „гудящий”, „жалобный”, „тревожный”, „изматывающий”, „терзающий сердце”. Dźwięk dzwonów oplata miasto niewidzialną siecią, wypełnia je, faluje, płynie, innymi słowy zdaje się konkretyzować pod postacią płynnego żywiołu, co może mieć związek

${ }^{34}$ G. Guźlak, Dzwony. Ich funkcje kulturowe $w$ literaturze i obyczajach XIX-XX wieku, Wydawnictwo Uniwersytetu Kazimierza Wielkiego, Bydgoszcz 2011, s. $59,62$.

35 J. Nowiński, Dzwon w tradycji i kulturze Europy, „Seminare” 1995, nr 11, s. 203. 
z multisensorycznym postrzeganiem rzeczywistości przez człowieka, który odbiera świat holistycznie, nie oddzielając wrażeń słuchowych od wzrokowych. Ponieważ w utworze Rubiny źródło dźwięku (dzwony), nie jest widoczne, podmiot percepcji zastępuje jego obraz, podobnie jak podczas słuchania organów, wizją wody, również silnie naznaczonej symboliką tanatyczną:

Он качался и плыл в колеблющихся сумерках, как тяжелая вода каналов ${ }^{36}$, раскачивалась невидимая сеть, опутывала шпили, крыши, купола, каналы... ${ }^{37}$

Powyższe oraz cytowany wcześniej fragmenty, mówiące o dzwonnicy Santa Maria-Formosa, z której „wypadały” gęste basy, „upuszczające” przypadkowe „bimy i bomy”, potwierdzają tezę o synestezyjnym odbieraniu bodźców zmysłowych przez podmiot percepcji, który postrzega dźwięk nie tylko jako wrażenie słuchowe, ale także jako przedmiot widzialny i posiadający odczuwalny przez człowieka ciężar.

Zastosowane przez autorkę zabiegi miały najwyraźniej na celu nadanie Wenecji rangi równoprawnego bohatera utworu, potraktowanie jej jako istoty ożywionej, posiadającej głos, lecz będącej jednocześnie swego rodzaju eksterioryzacją rozterek duchowych postaci literackiej. „Głos Wenecji”, ujawniający się jako dźwięk dzwonów, wydaje się wzywać bohaterkę, nawoływać ją, dręczyć, nakłaniać do zaakceptowania własnego losu, który okazuje się zbieżny z losem miasta:

Этот город [...] был так же обречен, как и она, а разница в сроках - семь месяцев или семьдесят лет - ... такая чепуха для бездушного, безграничного времени! И это предощущение нашей общей гибели, общей судьбы, вот что носится здесь, над водой каналов ${ }^{38}$.

Analiza motywów tanatycznych i wybranych elementów krajobrazu dźwiękowego Wenecji w opowieści Diny Rubiny Высокая вода венециианцев potwierdza postawione na wstępie hipotezy.

Przestrzeń Wenecji jest przestrzenią „wzrokocentryczną”. Świadczy o tym nie tylko fakt, że piszący o Wenecji nie konstruują szczegółowych opisów audiosfery, ale również opinie i refleksje wielu z nich,

${ }^{36}$ Д. Рубина, Высокая..., s. 27.

${ }_{37}$ Tamże, s. 38.

${ }^{38}$ Tamże, s. 38 . 
mówiące o dominacji zmysłu wzroku w postrzeganiu przestrzeni miasta i szczególnego rodzaju „malarskości” Wenecji, skłaniającej obserwatora do spoglądania na nią oczami artysty malarza. Wyjątkami są pisarze szczególnie wrażliwi na sensoryczną różnorodność przestrzeni, z reguły posiadający zawodowe kompetencje związane z używaniem jednego ze zmysłów. Dina Rubina, posiadająca, podobnie jak Jarosław Iwaszkiewicz, wykształcenie muzyczne, przywiązuje większą wagę do zjawisk dźwiękowych niż inni autorzy tekstów o tematyce weneckiej.

Wenecja w utworze przedstawiona została zgodnie z tradycją literacką, w której miasto kojarzone jest z takimi zjawiskami jak „śmierć”, „choroba”, „przemijanie”. Również percepcja przestrzeni dźwiękowej przez podmiot, czyli bohaterkę opowieści, ukształtowana została przez tego rodzaju kod kulturowy. Pejzaż dźwiękowy, będący źródłem ważnych bodźców sensorycznych, wywołuje silną reakcję emocjonalną bohaterki. Pełni również rolę „głosu miasta”, w którym wyraża się specyficzna więź umierającej kobiety z „umierającą” Wenecją.

Analiza opisów dźwięków umieszczonych w tekście Rubiny nasuwa jeszcze jeden wniosek:

wrażeniom akustycznym towarzyszą w utworze wrażenia wizualne, a nawet dotykowe. Ludzkie sensorium działa bowiem holistycznie: człowiek często reaguje na poszczególne zjawiska wszystkimi zmysłami. Można więc mówić o specyficznej polisensoryczności przedstawionych w utworze sonotopografii.

\section{REFERENCES}

Ackroyd, Peter. Wenecja. Biografia. Trans. T. Bieron. Poznań: Zysk i S-ka, 2015.

Brodski, Josif. Znak wodny. Trans. S. Barańczak. Warszawa: Zeszyty Literackie, 2016.

Czaja, Dariusz. "Szmery, szepty, krzyki. Muzyka wenecka.” 57-69. Prace Kulturoznawcze 2012, no. 13.

Gladysheva, Mariya, and Krinitsyn, Aleksandr. "Venetsiya v russkoy poezii XIX XX vekov.” Litera 2018, no. 1. 27 March $2018<$ https://www.e-notabene.ru/fil/ article_25264.html> [Гладышева, Мария, Криницын, Александр. "Венеция в русской поэзии XIX - XX веков”, Litera 2018, no. 1. 27.03.2109 <https:// www.e-notabene.ru/fil/article_25264.html>].

Górny, Konrad. “Antropologia, współczesności czy kultury?” Zeszyty Etnologii Wrocławskiej 2016, no. 1.

Guźlak, Gerard. Dzwony. Ich funkcje kulturowe w literaturze i obyczajach XIX-XX wieku. Bydgoszcz: Wydawnictwo Uniwersytetu Kazimierza Wielkiego, 2011.

Iwaszkiewicz, Jarosław. “Opowiadanie z kotem.” Idem. O psach, kotach $i$ diabłach. Warszawa: Czytelnik, 1968. 
Iwaszkiewicz, Jarosław. Podróże do Włoch. Warszawa: PIW, 1997.

Losev, Lew. "Real'nost' zazerkal'ya: Venetsiya Iosifa Brodskogo." Inostrannaya literatura 1996, no. 5, 28 March $2019<$ http://magazines.russ.ru/inostran/1996/5/ losev.html> [Лосев, Лев. "Реальность зазеркалья: Венеция Иосифа Бродского." Иностранная литература 1996, no. 5. 28.03.19. < http://magazines. russ.ru/inostran/1996/5/losev.html>].

Mednis, Nina. Venetsiya $v$ russkoy literature. Novosibirsk $1999<$ https://libking.ru/ books/sci-/sci-philology/457906-nina-mednis-venetsiya-v-russkoy-literature. html $>$ [Меднис, Нина. Венеция в русской литературе, 12.11.2019<https:// libking.ru/books/sci-/sci-philology/4579o6-nina-mednis-venetsiya-v-russkoyliterature.html $>$.

Mrówka, Kazimierz. Wenecja. Kraków: Wydawnictwo Formicula, 2009.

Muratow, Paweł. Obrazy Włoch. Wenecja. Trans. P. Hertz. Warszawa: Zeszyty Literackie, 2009.

Nowiński, Janusz. “Dzwon w tradycji i kulturze Europy.” Seminare 1995, no. 11.

Piotrowski, Grzegorz. Fortepian ze Stawska. Muzyka w prozie fabularnej Jarosława Iwaszkiewicza. Toruń: Wydawnictwo Adam Marszałek, 2010.

Rubina, Dina. Vysokaya voda venetsiantsev. Moskva: Litres, 2017 (digital edition) [Рубина, Дина. Высокая вода венецианцев, Москва: Litres, 2017 [цифровое издание].

Rybicka, Elżbieta. "Od poetyki przestrzeni do polityki miejsca. Zwrot topograficzny w badaniach literackich.” Eadem. Geopoetyka. Przestrzeń $i$ miejsce we wspótczesnych teoriach i praktykach literackich. Kraków: Universitas, 2014.

Schafer, Raymond Murray. The Soundscape. Our Sonic Enviroment and the Tuning of the World. Rochester, Vermont: Destiny Books, 1994.

Smirnov, Gleb. Metafizika. Moskva: OGI, 2017 [Смирнов, Глеб. Метафизика. Москва: ОГИ, 2017]

Szalewska, Katarzyna, Urbanalia - miasto i jego teksty. Gdańsk: Słowo/obraz terytoria, 2017.

Tsiv'yan, Tat'yana. “'Zolotaya golubyatnya u vody...' Venetsiya Akhmatovoy na fone drugikh russkikh Venetsiy." Eadem. Semioticheskiye puteshestviya. SanktPeterburg: ID Ivana Limbakha, 2001: 40-50. [Цивьян, Татьяна. “'Золотая голубятня у воды...' Венеция Ахматовой на фоне других русских Венеций. Eadem. Семиотические путешествия, Санкт-ПетербургИ: ИД Ивана Лимбаха, 2001: 40-50.] 